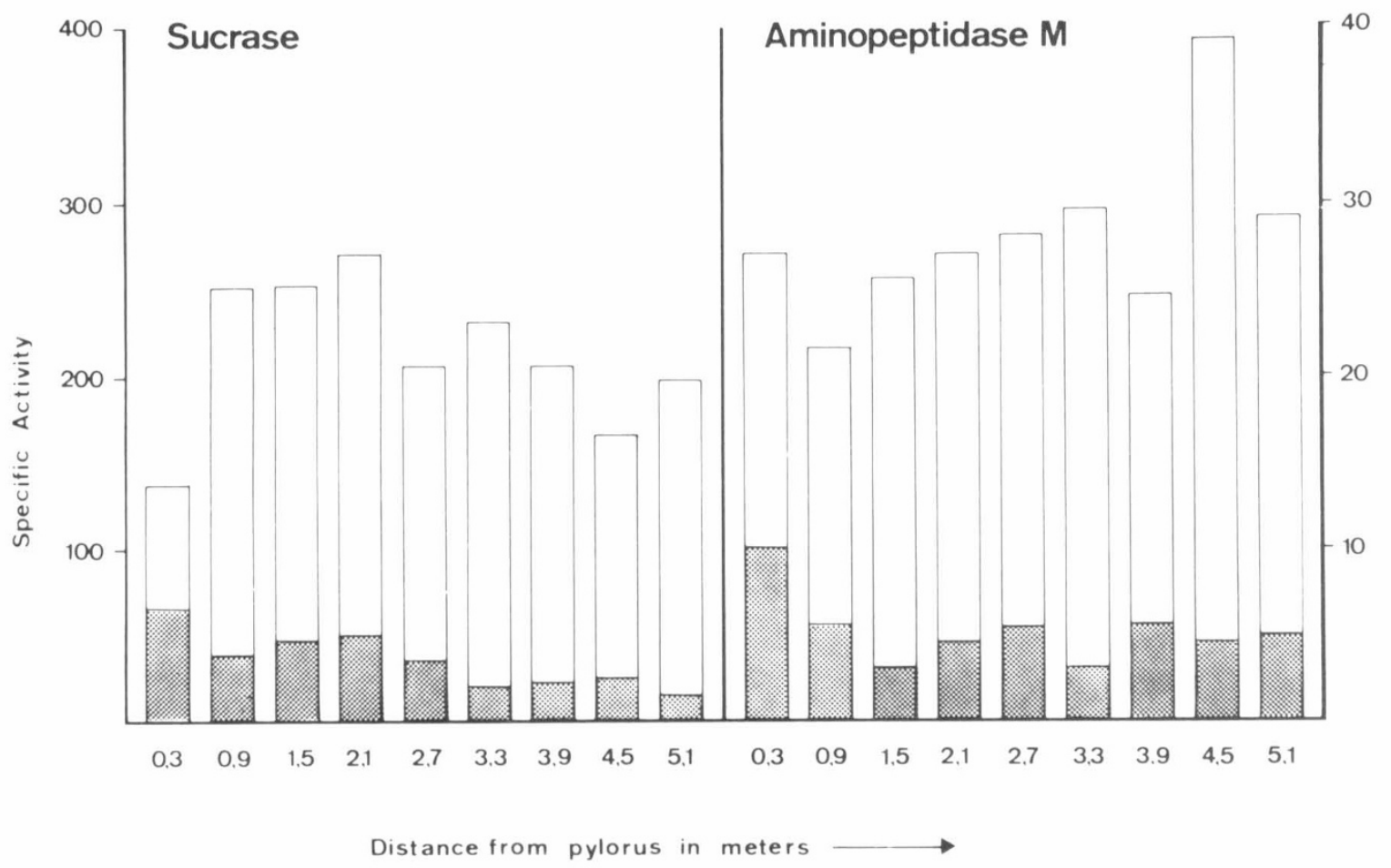

Fig. 2. Distribution of aminopeptidase $M$ and sucrase along the human small intestine. Details as in Figure 1.

REFERENCES AND NOTES

1. Andria, G., Cucchiara, S., DeVizia, B., DeRitis, G., Mazzacca, G., and Auricchio, S.: Brush border and cytosol peptidase activities of human small intestine in normal subjects and coeliac patients. Pediatr. Res., 14: 812 (1980).

2. Auricchio, S., Greco, L., DeVizia, B., and Buonocore, V.: Dipeptidylaminopeptidase and carboxypeptidase activities of the brush border of rabbit small intestine. Gastroenterology, 75: 1073 (1978).

3. Dahlqvist, A.: Assay of intestinal disaccharidases. Anal Biochem., 22: 99 (1968).

4. Lowry, O. H., Rosebrough, N. J., Farr, A. L., and Randall, R. J.: Protein measurements with the Folin phenol reagent. J. Biol. Chem., 913: 265 (1951).

5. Sterchi, E. E., and Woodley, J. F.: Peptidases of the human intestinal brush border membrane. In: B. McNicholl, C. F. McCarthy, P. F. Fottrell: Perspectives in Coeliac Disease. pp. 437-449 (MTP Press Limited, Lancaster, England. 1978).

6. Sterchi, E. E. and Woodley, J. F.: Peptide hydrolases of the human small intestinal mucosa: distribution of activities between brush border membranes and cytosol. Clin. Chim. Acta, 102: 49 (1980).

7. Sterchi, E. E., and Woodley, J. F.: Peptide hydrolases of the human small intestinal mucosa: Identification of six distinct enzymes in the brush border membrane. Clin. Chim. Acta, 102: 57 (1980).

8. The cooperation of Dr. A. Krneta is gratefully acknowledged.

9. This research was supported by grant $3.957-0.78$ from the Swiss National Science Foundation.

\title{
Letter to the Editor: Distribution of the Brush Border Peptidase Activities along the Small Intestine
}

\author{
SALVATORE AURICCHIO
}

Clinica Pediatrica, II Facolta de Medicina e Chirurgia, Via Sergio Pansini 5, 80131 Napoli, Italy

We have studied (1) the distribution of the peptidase activities of the brush border along the small intestine of eight human fetuses aged between 16 and $22 \mathrm{wk}$, and we have found results which are similar to those reported by Sterchi in his letter and by us in previous studies in rabbit (2): the peptidase activities are higher in the distal third than in the proximal one.

Nevertheless, we think that the presence of normal levels of peptidase activities in the proximal part of the small intestine in coeliac patients in histologic remission suggests that these activities are normal along the small intestine and that no primary deficiency of these peptidase activities exists in the coeliac disease.

\section{REFERENCES AND NOTES}

1. Auricchio, S., Stellato, A., and De Vizia, B.: Development of brush border peptidases in human and rat small intestine during fetal and neonatal life. Submitted to Pediatr. Res.

2. Auricchio, S., Greco, L., DeVizia, B., and Buonocore, V.: Dipeptidylaminopeptidase and carboxypeptidase activities of the brush border of rabbit small intestine. Gastroenterology, 75: 1073 (1978). 